RESEARCH ARTICLE

\title{
The partnership co-creation process: Conditions for success?
}

*Susan Smith and Kimiya Akhyani, Department of Accounting and Finance, University of Sussex, United Kingdom.

Dan Axson, Department of Technology Enhanced Learning, University of Sussex, United Kingdom.

Andrei Arnautu, Department of Philosophy, University of Sussex, United Kingdom.

Ilina Stanimirova, Department of Media, Journalism and Cultural Studies, University of Sussex, United Kingdom

Contact: susan.smith@sussex.ac.uk

\section{ABSTRACT}

Staff-student partnership activity continues to increase across the higher education sector, expanding to encompass a broad range of initiatives. Numerous frameworks and typologies have been proposed to help organise the literature and facilitate comparisons among different types of partnerships. The research reported here draws on a case study of a quality-enhancement staff-student partnership to identify the stages of the partnership co-creation process. It argues that the establishment of partnership values is intertwined with the stages of the co-creation process and is critical to the partnership's success. This research contributes to practice and the literature by offering a practical approach to managing a staff-student partnership, adding to work on quality enhancement partnerships, and extending prior work evaluating partnership activity from the perspectives of multiple stakeholders.

KEYWORDS

partnership, values, co-creation, partnership process, evaluation

Practices that seek to develop staff-student partnerships are increasingly common in higher education settings (Bovill, 2019; Healey et al., 2014; Matthews et al., 2019), are increasingly diverse (Bovill, 2017), and are extending beyond their original boundaries rooted in research, teaching, learning, and assessment (Healey \& Healey, 2018). Some scholars conceptualise partnership as a threshold concept in educational development (Cook-Sather, 2014; Marquis et al., 2016) which, if it can overcome the entrenched power relations (Deeley \& Bovill, 2017), has the capacity to profoundly influence participants' behaviour and thinking (Curtis \& Anderson, 2021). Adopting partnership approaches offers higher education institutions a means of "optimising their innovation processes" (Naylor et 
al., 2021, p. 1028) and of moving away from consumerist models of higher education (Healey et al., 2016).

Healey et al. (2014) describe partnership as a process: "It is a way of doing things, rather than an outcome in itself"(p. 7). It involves a high level of equality and contribution from partners (Bovill, 2017), and the nature of participation can vary throughout the duration of the partnership, as illustrated by Bovill's (2017) participation matrix (p. 3). Partnerships are frequently small scale and context dependent (Healey \& Healey, 2018), potentially limiting generalisations, although there is increasing focus on theorising partnership processes (Matthews, Cook-Sather, et al., 2019). Examples include linkages to Bourdieu's theories of capitals and habitus (Matthews, 2017) and feminism (Cates et al., 2018; Mercer-Mapstone \& Mercer, 2018). To help organise and explain partnership work, scholars have proposed a range of frameworks and typologies to map and categorise partnership activity (Bovill et al., 2016; Bovill, 2020). Such frameworks typically focus on the nature of the partnership (e.g., curriculum design or redesign) (Bovill \& Bulley, 2011).

Whilst recognition of the contextual nature of each partnership is important (Healey \& Healey, 2018), a focus on the stages of the partnership process can offer a framework to foster some generalisation. Partnerships are closely associated with the establishment of values to support the disruption of established power relations between staff and students for the duration of the work. An explicit framing of partnership values helps to set expectations, particularly since student partners do not generally have prior experience of working with staff on such projects (Luo et al., 2019). This also helps to foster a sense of collective ownership of the partnership outcomes (Marie \& McGowan, 2017).

Healey and Healey (2018) identify two broad groupings of partnership activities: (a) learning, teaching and research, and (b) quality enhancement. This case relates to the quality enhancement grouping of student partnerships (Healey \& Healey, 2018) and relates to a staff-student partnership constituted to co-create new generic assessment criteria to be used across all taught programmes at one school in the university. We adopted a partnership process to ensure that the criteria were designed to support the development of student assessment literacy (Deeley \& Bovill, 2017). Existing partnership work in assessment identifies challenges associated with teachers and students working closely together at the module level (Deeley \& Bovill, 2017). These concerns were substantially mitigated in the case study we report on here through working to co-create the generic school-level rather than assessment-specific criteria.

To date, partnerships have been adopted to develop assessment criteria at the module level (Bergmark \& Westman, 2016; Bovill, 2020; Deeley \& Brown, 2014) and evaluate teaching and learning (Cook-Sather et al., 2020), although Curtis and Anderson (2021) report that there are few projects that focus on program-level assessment. Some partnerships extend across departments (Snelling et al., 2019) and cohorts (Hunt \& Hunt, 2017), whilst others have a limited impact beyond the immediate context (Marie \& McGowan, 2017). The current case draws on and adds to this body of work through the adoption of partnership co-creation processes at the school level.

This study draws on the principles of design thinking (Snelling et al., 2019) and value co-creation (Dollinger et al., 2018) to illuminate the mapping of partnership processes to the values of partnership (Healey et al., 2014). Findings establish a five-stage process that maps to the establishment of partnership values. The process offers a practical framework which can help staff and students navigate the variability around roles, contexts, and outcomes. In so doing, it helps to address planning around the time constraints for the partnership (Bovill, 
2017) and acts as a signalling mechanism for participants. It adds to the literature on quality enhancement partnerships (Healey \& Healey, 2018) and highlights the multifaceted nature of partnership evaluation activity.

The following section discusses the staff-student partnership literature. We then link design thinking with partnership co-creation activity. This is followed by a section that outlines the case context and the research method that was adopted in this research. The research is then presented prior to the discussion of the findings and the conclusions.

\section{STAFF-STUDENT PARTNERSHIPS}

Staff-student partnership can span a broad range of activities. Therefore, it is important to outline a definition at the outset. A broadly accepted definition of partnership is that it is "a collaborative, reciprocal process through which all partners have the opportunity to contribute equally, although not necessarily in the same ways, to curricular or pedagogical conceptualization, decision making, implementation, investigation or analysis" (Cook-Sather et al., 2014, pp. 6-7).

Terminology can be mixed in the literature relating to staff-student partnerships, often referring to students as partners, producers, or change agents and to co-creation activity (Bovill, 2019). Bovill et al. (2016) have argued that all partnership offers co-creation and student engagement, whilst not all co-creation involves partnership. In this paper we use the term staff-student partnership to refer to the case.

Further, the composition of staff-student partnerships can vary significantly, including students working with other students, academics, professional services staff (administrators), and/or alumni (Matthews, 2017). In addition, the partnership may be embedded as part of the curriculum (Bovill, 2020) or external to it (Marie \& McGowan, 2017) and may be either a remunerated or voluntary activity (Marquis et al., 2018). All of these choices have implications for the nature of the partnership and, relatedly, the explicit development of partnership values.

Staff-student partnerships seek to disrupt the established power structures within higher education, which is a requirement to create the conditions for successful co-creation (Dianati \& Oberhollenzer, 2020). The power structures of academia frame the positions of the academic and the student as fixed and perpetuate these differences through mechanisms such as the structures of the lecture rooms and language used by academics (Bourdieu, 1988). The power structures must be dissolved for the duration of the partnership for it to claim to be a true partnership (Cates et al., 2018). This requires a careful approach to establishing the conditions for the partnership (Dollinger et al., 2018).

The conditions for establishing successful partnerships often relate to establishing the values of productive partnership (Cook-Sather et al., 2014; Healey et al., 2014). All partnership participants need to be able to challenge the status quo and offer their perspectives during the process (Healey et al., 2014). Establishing the values of the partnership is therefore critical to its eventual success (Luo et al., 2019). The values associated with partnership have been explicated in the literature, with some value groupings more granular in nature than others, although they broadly converge around authenticity, inclusivity, reciprocity, empowerment, trust, challenge, community, and responsibility (Healey et al., 2014); respect, responsibility, and reciprocity (Cook-Sather et al., 2014); agency, accountability, and affinity (Cates et al., 2018); and respect, communication, understanding, and responsibility or commitment (Luo et al., 2019). Luo et al. (2019) found that the focus of responsibility for enacting the values varied: for some 
values the responsibility was mutual between the staff and students (e.g., respect), whilst for others (e.g., understanding), there was a greater responsibility for staff to develop their understanding of students' circumstances.

In this study, we map the stages of partnership-establishing the partnership, partnership operation and atmosphere, and partnership outcomes (Smith et al., in press)to the extended partnership values (Healey et al., 2014), resulting in a focused grouping of values by partnership stage. We identify authenticity, reciprocity, and inclusivity as important antecedents to the partnership process (Smith et al., in press). One value that underlies staff and student participation in co-creation is authenticity (Curtis \& Anderson, 2021; Dollinger \& Lodge, 2020). Reciprocity requires that partnership participants have the opportunity to contribute and that their contributions are valued by the partnership (Cates et al., 2018). Establishing an inclusive environment helps to actively reduce any identified barriers to engagement (Healey et al., 2014; Matthews, Mercer-Mapstone \& Bovill, 2020; Marquis et al., 2019).

Participants develop the value of empowerment throughout the partnership operation and atmosphere (Smith et al., in press). Scholars have previously considered empowerment at three levels: intrapersonal, interpersonal, and within communities (Hunt \& Hunt, 2017). Fostering an environment where all participants feel sufficiently empowered to contribute is critical to achieving the aims of partnership activity, and arguably empowerment builds through the three levels during a successful partnership.

Other partnership research offers co-created principles for partnership: diverse contributions, shared responsibility, and structured reflection (Dianati \& Oberhollenzer, 2020). The first two principles map to the partnership values of inclusivity and shared responsibility. Reflection also emerges as an important theme in the partnership literature (Matthews, 2017), helping participants understand their experiences of the partnership process and forming part of the overall partnership evaluation. This reflective evaluation supports the personal benefits reported in the literature (e.g., sense of self and selfawareness) (Matthews et al., 2018). Reflection recognises the fact that positions within the partnership are not fixed and evolve as the project progresses, although typically it is staff who initiate the partnership process (Bovill, 2017) from their positions of institutional power. It is these positions which classify which endeavours are suitable for partnership work and which are not.

The aim, scale, and timeframe are all important factors in the partnership process (Healey \& Healey, 2018). Participants can relate partnership aims to an outcome (e.g., a sense of community) or an output (e.g., assessment criteria), and it may be the case that different conditions are required to achieve different outcomes. In addition, different partnership processes may have developed in the two areas identified by Healey and Healey (2018): teaching, learning and research, and quality enhancement. To date, partnerships in teaching, learning, and assessment have received more attention than those related to enhancement (Healey \& Healey, 2018).

Process-based approaches offer participants the potential to structure partnership activity, facilitate increased comparability, and enable values-driven partnership activity in ways that are replicable at scale across an institution, irrespective of the focus, be it outcome or output. Progress tracking during the partnership allows for real-time feedback and adjustments to the partnership conditions as it progresses (Cook-Sather et al., 2019). This is often a task undertaken informally by the facilitator (often an academic developer) on larger projects. 


\section{DESIGN THINKING APPLIED TO STAFF-STUDENT PARTNERSHIPS}

Educators have adopted a design-thinking approach (Snelling et al., 2019) in a curriculum development context. Design thinking focuses on the process and is fully scalable and replicable, offering a framework to explain and understand differences in partnership processes and participant outcomes. The design-thinking framework comprises five stages:

1. empathising or developing a common understanding of the problem;

2. defining a shared purpose to the problem;

3. ideation or exploring potential solutions from multiple perspectives;

4. prototyping or developing an initial solution, seeking feedback, and iterating the approach; and

5. testing or placing the solution in its expected context to identify whether it addresses the problem identified (Plattner et al., 2015).

The Snelling et al. (2019) study focused on three small-scale examples of curriculum partnership, one of which was at the departmental level, with the other two at the course level. Their first two examples co-created defined outputs whilst the third co-created a defined outcome (i.e., improved performance on a course topic). This work points to the potential for drawing on design-thinking approaches for staff-student partnerships within the curriculum area. Such curricular partnerships could meet two important needs, as Healey et al. (2016) explain:

Learning and working in partnership has also been proposed as a pedagogically sound alternative to consumerist models of $\mathrm{HE}$ [higher education], and a constructive response to (inter)national policy drivers emphasizing the importance of student engagement and teaching quality for the transformation of $\mathrm{HE}$ fit for a contemporary world. (Healey et al., 2016, p. 1)

Healey's view of partnership is the antithesis of the consumerist model and stands in contrast to other perspectives on partnership activity which seek to adapt market-based approaches to the university context (Dollinger et al., 2018). Even where market-oriented outcomes are explicit goals, co-creation can be successful (Dollinger \& Lodge, 2020). However, others caution against staff-student partnerships being hijacked by managers to promote the student-as-consumer agenda (Healey \& Healey, 2018). There is some evidence that partnership models may challenge student perceptions (often unconscious) that academics should lead the work (Luo et al., 2019). This indicates that there is some need to explicitly articulate and discuss the partnership values at the outset.

In response to the market-based narrative, practitioners have developed approaches rooted in value co-creation (Dollinger et al., 2018). Such work adopts a consumersatisfaction perspective, arguing that there are two important dimensions to such projects: creation of the value proposition with the consumer and an ongoing value in use (Ranjan \& Read, 2016). Dollinger et al. (2018) suggest three ways in which co-production can be adapted to staff-student partnerships through the constructs of knowledge, equity, and interaction. Such constructs attract comparisons to partnership values previously outlined as conditions for successful partnerships (Healey et al., 2014). The proposition of value in use offers the possibility of evaluation of the project outcomes from the perspective of the student through considering "how the value of co-production affects the value they see or 
use" (Dollinger et al., 2018, p. 216). However, this approach omits important measures of value, which Dollinger et al. (2018) explicate using the constructs of innovation generation, sharing of knowledge, and developing strong relational ties.

The literature indicates that existing approaches from other fields may offer useful frameworks for partnership activity but also that attention to partnership values is an important part of moving from a market-based approach to one which is replicable in the context of higher education.

\section{RESEARCH METHOD}

The case context is a staff-student partnership which was constituted during summer 2020 to revise generic assessment criteria within the university business school. We therefore categorise it as a project focused on a defined output related to quality enhancement activity (Healey \& Healey, 2018).

The project ran for 7 weeks from late July and concluded with the publication of the revised criteria and supporting resources developed as part of the project. Students were recruited to the project through the university connector programme, funded via its Access and Participation Plan (University of Sussex, 2020). The project was initiated to address the continued poor feedback from students in relation to assessment criteria, including via student representatives and the annual National Student Survey (NSS) (Office for Students, 2018). Student recruitment and training were managed by the connector programme prior to the start of the project (Mercer-Mapstone \& Bovill, 2020). All students, known as student connectors, were paid for their work on the project (Marquis et al., 2018).

This process led to the recruitment of six students to the project. We drew them from a range of years of study and degrees and from within and outside the business school to represent different experiences. We individually selected staff to join the project to ensure representation of the various departments and positions and to help with the implementation following the project's conclusion. We recognised staff participation via a certificate (Mercer-Mapstone \& Bovill, 2020) and the opportunity to develop scholarship outputs from the experience (Curtis \& Anderson, 2021).

Following the conclusion of the project, we invited students who were continuing their studies to participate in the research project. Three of the four who remained as students indicated that they wished to do so. We received institutional ethical review approval (ER/SS706/16) to conduct a series of semi-structured interviews with project participants to investigate the partnership process.

Due to the continuing pandemic, we conducted all interviews via video interview between 2 December 2000 and 3 February 2021, with each lasting approximately 30 minutes. We interviewed five students along with five staff members (both faculty and professional services). All researchers coded transcriptions manually using a thematic analysis approach (Braun \& Clarke, 2006). The process continued until we were satisfied that we had identified the themes and had selected representative quotes.

\section{FINDINGS}

We identified five stages of our process through our analysis of the interview data. These were: problematising, listening, creating, implementing, and evaluating. Problematising involves specifying the purpose of the partnership (i.e., its defined outcome or output) (Healey \& Healey, 2018). This stage also involves achieving a collective understanding of the desired aims. Listening involves unpacking the challenges from 
multiple perspectives as well as identifying how to broaden the range of voices heard during the project (e.g., via undertaking focus groups or a short survey to seek further student feedback). This then led to the creation phase where we debated different suggestions and refined them within the weekly plenary sessions. Once we completed the creation stage, we embarked on the implementation phase with both a staff- and student-facing communication plan to ensure the rollout in the new academic year. Whilst the evaluation of the outputs is ongoing, findings indicate that evaluation can take place on multiple levels: individual, school, and university.

\section{Problematising}

We identified problematising as the initial phase. It is essential that those who join a staff-student partnership understand the purpose of the project and its scope. In this case, we recruited the students with a role description that outlined that the project would focus on the school assessment criteria, so they had some expectation of the project purpose. We recruited staff to join the project as a result of their roles within the assessment processes (e.g., course directors, director of teaching and learning).

The initial session involved reinforcing the values of the project and encouraging everyone to contribute to the discussion by exploring the background to the project. This approach helped to set expectations for all of the project participants, as was explained by a staff partner: "the tone of the project was set and maintained all the way through, which was very beneficial for the success" (Staff 1).

Initially, students reported feeling apprehensive and unsure about how the project would progress and what would be expected from them. One student noted, "we just had to familiarise ourselves [with] what we were going to do because initially . . . the students did not know what was going to happen during this project" (Student 5).

Gradually we moved from anonymous input to polling tools to a discussion as the primary means of interaction during the plenary sessions. Initially, the group interrogated the purpose of assessment via a word cloud and of feedback using an anonymous, free textresponse tool. At the same time, we presented data that identified that the school's performance could be improved. This led to discussion of the challenges of revising the school's assessment practices, reflecting the increasing confidence of the student connectors to contribute to the discussion. As one student partner explained,

It was, "guys we want your perspective on what's not working with the business school at the moment with the assessment criteria, we want your perspective, we want to understand why that's the case", and staff have always [made]sure to reiterate the fact that they wanted honesty. (Student 1)

We continually reinforced partnership values so that students were clear that their views were valued by the group.

\section{Listening}

Before starting the co-creation phase, we engaged in significant discussion to identify and interrogate the specific issues and perceptions of both staff and students about the existing assessment criteria. One staff participant explained that "the early meetings were very broad and that did feel like a brain dump of what was going on. And I think that's where we learned a lot. Just hearing from you guys [students] and from faculty" (Staff 4). 
During this phase, we continued to reinforce the values for a successful partnership, making participants feel that their perspectives were being listened to:

It was mainly because you did feel like people really wanted to listen to what you had to say and really wanted to, you know, improve the marking criteria, not just as a student, but also from the staff perspective as well. (Student 3)

We extended the listening phase to incorporate other perspectives to ensure that the team was not self-affirming or missing something fundamental. We realised this goal through the student connectors organising a student survey and incorporating the data. In this stage we uncovered some surprising differences in perceptions between the staff and student members of the group. For example, it became clear that terminology related to assessment was not universally understood and that "even words that were very clear to me or other members of faculty were not clear to the students" (Staff 3).

We would not have identified some of these differences without the ongoing dialogue that took place during this phase of the project. It revealed that what is often taken for granted or assumed is not universally clear, and it started to change mindsets for the creation of the assessment criteria.

\section{Creating}

In the creation phase we used the data gathered through the discussions in the listening phase along with the survey feedback, NSS data, and comments to reflect on the challenges. We also drew on the quality standards and benchmarked our proposals against other assessment criteria.

Students recognised the importance of working together to create assessment criteria that served the multiple constituencies within the business school. For example, one student highlighted the importance of reflection to provide solutions, but also incorporate other people's perspective or thoughts on things to kind of shape a solution that kind of suited everyone rather than one kind of student [or] myself as a student" (Student 3).

Interestingly, differences emerged between student and staff perceptions of the time spent on the creation of the new criteria. For example, one student observed: "planning of the new assessment criteria, this process took a long time. But essentially it was the most important part of our project" (Student 5). In contrast, staff viewed the same process as fairly quick: "then we very quickly got into tightening it up into some kind of output" (Staff 4). The comments may indicate a need to manage expectations of how long each phase of the project will take.

The students were empowered to work on the student-facing resources and communications plan, as it was important that the final output was designed in a manner that was accessible to students and that the communications were also student-friendly. Consider this student's reflection on their role in this process:

I was given a lot of creative freedom. For example, I got to work on the communications for this project and also, I got to work in a team to create this animation for our project and I think those things really helped me become more organized, but also, they helped me show what I was good at. (Student 5) 
The quality of the output created by the students was extremely high, and staff members were amazed by what had been achieved.

\section{Implementing}

We commenced the implementation at the business school's annual away day in September 2020. The annual away day is where the school management team share their plans for the upcoming academic year. This was where we showed a short film of the project and made the criteria and supporting materials available to faculty. Not all staff members had anticipated that the video would be as successful as it was in explaining the revised criteria to students: "when the video came out and it was animated, I thought it might have been a risk... but I really liked it" (Staff 1 ).

We housed the faculty resources on the virtual learning environment (VLE), and they were accompanied by training sessions on incorporating the criteria into marking rubrics and delivering linked feedback. In addition, one team member wrote a blog for the school's teaching and learning blog. We also updated the school VLE program and course templates to automatically import references to the new criteria.

We continued the implementation phase with student-led sessions during welcome week, a student blog posting, and the release of the student-created animation, which students found particularly engaging: "I would say the ... phase of just distributing the criteria was the most fun for me" (Student 5). We reinforced the implementation for the second semester to ensure that new starters and those who may not have taught in the first semester were fully aware of the revised assessment criteria and how to use them.

\section{Evaluating}

Participants can undertake an evaluation of a partnership project on a number of levels: individual, school, and university.

They might undertake a student-level evaluation against the role description (Table 1 below) used to recruit the student connectors to the project. 
Table 1: Evaluation against connector role description

\begin{tabular}{|c|c|c|}
\hline RESPONSIBILITIES & SKILLS DEVELOPED & EVALUATION \\
\hline $\begin{array}{l}\text { Work with university staff to create a useful tool for } \\
\text { students to better understand the school marking } \\
\text { criteria of specific courses. }\end{array}$ & $\begin{array}{l}\text { Collaboration, time } \\
\text { management, synthesis } \\
\text { of data }\end{array}$ & $\begin{array}{l}\text { Achieved - } \\
\text { revised } \\
\text { assessment } \\
\text { criteria } \\
\text { developed }\end{array}$ \\
\hline $\begin{array}{l}\text { Work with university staff to create tools for students } \\
\text { to better understand and improve based on feedback } \\
\text { on performance, tasks, and assessments. }\end{array}$ & $\begin{array}{l}\text { Collaboration, } \\
\text { communication }\end{array}$ & $\begin{array}{l}\text { Achieved - } \\
\text { project involved } \\
\text { both staff } \\
\text { (academic and } \\
\text { professional } \\
\text { services) and } \\
\text { students }\end{array}$ \\
\hline $\begin{array}{l}\text { Find inventive ways to seek and gather student } \\
\text { feedback on existing and proposed marking, } \\
\text { assessment, and module criteria to address } \\
\text { weaknesses and improve them. }\end{array}$ & $\begin{array}{l}\text { Active listening, } \\
\text { evaluation of data, and } \\
\text { producing } \\
\text { recommendations }\end{array}$ & $\begin{array}{l}\text { Achieved - } \\
\text { students initiated } \\
\text { a survey }\end{array}$ \\
\hline $\begin{array}{l}\text { Together create a communication plan that ensures } \\
\text { students better understand, engage, and can build } \\
\text { upon their learning using learning criteria for courses } \\
\text { and modules. }\end{array}$ & $\begin{array}{l}\text { Collaboration with } \\
\text { others, communication } \\
\text { skills }\end{array}$ & $\begin{array}{l}\text { Achieved - both } \\
\text { students and } \\
\text { faculty } \\
\text { communications } \\
\text { plan developed }\end{array}$ \\
\hline
\end{tabular}

Further evaluation data was derived from the students' own reflections: "I think it's helped me develop a lot of skills, time management, working adaptably, I think especially with COVID and the pandemic" (Student 1). Research frequently reports employability skills development as a student outcome of partnership activity (Mercer-Mapstone et al., 2017). The university connector programme is specifically designed to attract students who do not necessarily have pre-existing work experience or who would struggle to balance paid work with their studies. As a result, the opportunity to develop such skills is critical to the students. The students all developed online collaborative working skills, as the project ran entirely online during the COVID-19 pandemic. They have since called upon these skills during their studies or subsequent employment: "I enjoy the fact that people now find the assessment criteria more accessible and I think that speaks for itself" (Student 1).

We derived an evaluation of the staff experience of participating in the project from the interview process along with observed scholarship outputs from several participants. The scholarship outputs (e.g., blog, contributing to workshops) can be used as evidence in the individual's annual appraisal and/or promotion cases. The interviews highlighted the reported benefits for staff members, for example, one staff member explained: "It's only when ... you work in teams that you realise that actually you know it's not that way at all or there are other ways of looking at this or interpreting this. So, it's opened my eyes, most definitely" (Staff 1). The interviewees typically reported the benefits of being open to learning from others. 
We are engaged an ongoing evaluation at the school level and will be guided by the following indicators included in Table 2 (below).

Table 2: Evaluation of the project output at school level

\begin{tabular}{|c|c|c|}
\hline EVALUATION & TOOL & MEASURE \\
\hline $\begin{array}{l}\text { Adoption of revised criteria } \\
\text { by academics }\end{array}$ & $\begin{array}{l}\text { All assessments must have } \\
\text { clear marking criteria } \\
\text { All programme VLE sites } \\
\text { have criteria links } \\
\text { embedded into school } \\
\text { template } \\
\text { All course VLE sites have } \\
\text { criteria links embedded into } \\
\text { assessment section }\end{array}$ & $\begin{array}{l}\text { Internal moderation acts as } \\
\text { monitor } \\
\text { \% of VLE sites are audited } \\
\text { each semester by the } \\
\text { Technology Enhanced } \\
\text { learning team }\end{array}$ \\
\hline $\begin{array}{l}\text { National Student Survey } \\
\text { (NSS) }\end{array}$ & $\begin{array}{l}\text { Improved scores for Q8, } \\
\text { "The criteria used in } \\
\text { marking have been clear in } \\
\text { advance" }\end{array}$ & $\begin{array}{l}\text { NSS results publication- } \\
\text { summer 2021; } 2 \text { out of six } \\
\text { subject areas increased } \\
\text { satisfaction, } 3 \text { subject areas } \\
\text { were within the overall } \\
\text { annual movement of the } \\
\text { benchmark (-2.8\%), and } 1 \\
\text { declined outside of the } \\
\text { subject benchmark. }\end{array}$ \\
\hline $\begin{array}{l}\text { Staff-student experience } \\
\text { group feedback }\end{array}$ & Improved verbal feedback & Meeting minutes \\
\hline
\end{tabular}

The interviews indicated some encouraging signs of adoption by faculty: "Lecturers are actually touching more on the assessment criteria. I see some clear reminders on how to use assessment criteria and I can also see that it's more visible to me as a student" (Student 4).

At the university level, we see the project as a successful example of a staff-student partnership, and at least one other school is replicating the work: "so it's really cool to see how, you know, something that started with us is kind of going into other schools as well" (Student 5). We are also engaged in ongoing evaluation processes at a school and institutional level.

\section{DISCUSSION}

Rather than seeking to categorise staff-student partnerships (Healey et al., 2014) or to develop a typology (Bovill et al., 2016; Bovill, 2019), the partnership co-creation process developed during this project charts the partnership phases (see Figure 1 below). Whilst this process grew from one context-a project with a defined output-the staff partners have since applied it as a framing tool in two other contexts with desired outcomes (Healey \& Healey, 2018). The process transcends the context (Healey \& Healey, 2018) and helps to create a framework for partnerships whereby different phases can be expanded or 
contracted as required. Participants in staff-student co-creation partnerships can use this partnership framework as a tool to help frame the value-based dialogue that is critical to partnership success (Luo et al., 2019) and to respond to the importance of dialogue with those who are unfamiliar with partnership work at the outset (Luo et al., 2019).

Our five-stage process has some similarities to the design-thinking framework (Snelling et al., 2019). However, we see the establishment of the critical antecedent partnership values (Smith et al., in press) at the start of the partnership as going beyond design thinking's end-user-focused empathising stage (Plattner et al., 2015). Foundational partnership values include authenticity, reciprocity, and inclusivity, which foster feelings of trust (Marie \& McGowan, 2017). We see the problematising phase as substantially similar to the defining phase (Plattner et al., 2015). This stage explicitly addresses prior findings, which have identified that students can feel unfamiliar with the partnership environment (MercerMapstone et al., 2017), along with role confusion and lack of confidence (Dollinger \& Lodge, 2020).

The listening phase explicitly encourages the participants to listen to the diverse perspectives offered and seek validation with a wider group (i.e., staff and students beyond the project team). Taken together, the problematising and listening stages establish an atmosphere where participants start to experience empowerment (Hunt \& Hunt, 2017) and where traditional power differentials dissolve. The creating phase combines ideating and prototyping (Plattner et al., 2015) from design thinking, whilst testing (Plattner et al., 2015) is split between the creating, implementing, and evaluating phases of the process. At this stage, the participants should be sufficiently empowered to share innovative ideas and shape them in conjunction with other members of the partnership group.

The implementing phase is where the project team shares responsibility for the outcomes and feels that they have been part of a partnership community. These values are critical to the ability of the partnership to reach its intended goal. This stage also raises important questions around the responsibility for the sustainability of the partnership outcomes beyond the context of the partnership and whether this ultimately rests with the staff who have the ability to embed the outcomes within institutional processes (Marie \& McGowan, 2017).

The partnership co-creation process recognises that the higher education environment goes beyond the design of products and services and extends to policies and procedures which require a detailed implementation plan and may not offer an immediate solution implied by the testing phase (Plattner et al., 2015).

In our findings, we identified the evaluating phase as an important additional stage for staff-student partnerships. We found the evaluation to be multifaceted in staff-student partnerships and that it can occur at the level of the project participants (both staff and students) (Luo et al., 2019; Matthews et al., 2019), at the level of the project outcomes, and the level of the broader institution (Dollinger \& Lodge, 2020). As a result, some projects may be successful at one level but not at others. 


\section{Figure 1: Staff-student partnership co-creation process}

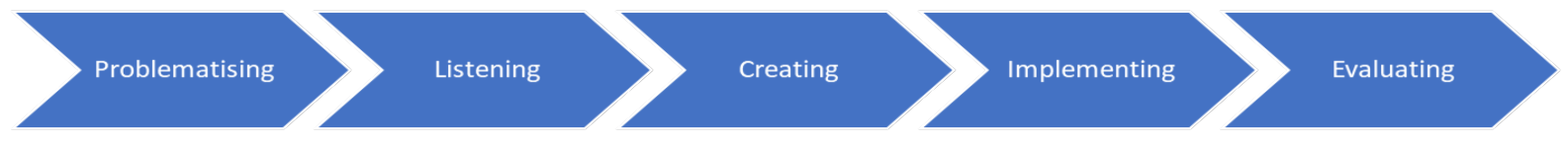

\section{CONCLUSION}

The research we report here adopts a case-study approach to outline the stages of the partnership co-creation process. It offers contributions to both the literature and practice. It contributes to the staff-student partnership literature by building on and extending prior work (Dollinger et al., 2018; Dollinger \& Lodge, 2020; Snelling et al., 2019). The process seeks to embed values for success rather than translate market-based approaches (Ranjan \& Read, 2016) to the partnership process. By interacting closely with the established values of staff-student partnerships (Cates et al., 2018; Cook-Sather et al., 2014; Healey et al., 2014; Luo et al., 2019), the process offers an approach through which the traditional hierarchies of higher education are dissolved. For those involved in staffstudent partnerships, motivations are authentic rather than profit-based or instrumental.

The process offers a practical approach to framing partnership work from the inception of the project, thereby reducing anxiety and developing a shared understanding of the partnership process, and to how the partnership maps to underpinning values, ensuring they form part of the dialogue throughout (Luo et al., 2019). This makes the process accessible to a broader range of staff as an approach. Further research could include a focus on specific stages of the co-creation process, for example, the complex nature of the evaluating phase.

Limitations of the research include the small scale of the partnership project and the fact that the process may not be generalisable to projects beyond the enhancement grouping (Healey \& Healey, 2018). Due to the one-off nature of staff-student partnerships, the same project team will not carry out any further iteration of the output, which may impact how the output is treated and ultimately evaluated. It remains to be seen how the process might be applied to detailed learning, teaching, and research student partnerships outlined by Healey and Healey (2018) (e.g., peer learning and assessment, undergraduate research). Snelling et al.'s (2019) work with design thinking (Plattner et al., 2015) indicated that there is likely to be some potential for adoption in relation to learning, teaching, and assessment co-creation contexts.

The research was successfully reviewed according to the University of Sussex research ethics approval process (ER/SS706/16). 


\section{NOTE ON CONTRIBUTORS}

Susan Smith is associate dean (education and students) at the University of Sussex Business School at the University of Sussex, UK. She is a senior lecturer in accounting.

Dan Axson is an academic developer at the University of Sussex, UK.

Kimiya Akhyani is a graduate of the University of Sussex Business School, University of Sussex, UK.

Andrei Arnautu is a graduate of the University of Sussex, UK.

Ilina Stanimirova is a graduate of the University of Sussex, UK.

\section{REFERENCES}

Bergmark, U., \& Westman, S. (2016). Co-creating curriculum in higher education: Promoting democratic values and a multidimensional view on learning. International Journal for Academic Development, 21(1), 28-40. https://doi.org/10.1080/1360144X.2015.1120734

Bourdieu, P. (1988). Homo Academicus. Stanford University Press.

Bovill, C. (2017). A framework to explore roles within student-staff partnerships in higher education: Which students are partners, when, and in what ways? International Journal for Students as Partners, 1(1). https://doi.org/10.15173/ijsap.v1i1.3062

Bovill, C. (2019). A co-creation of learning and teaching typology: What kind of co-creation are you planning or doing? International Journal for Students as Partners, 3(2), 9198. https://doi.org/10.15173/ijsap.v3i2.3953

Bovill, C. (2020). Co-creation in learning and teaching: The case for a whole-class approach in higher education. Higher Education, 79(6), 1023-1037.

https://doi.org/10.1007/s10734-019-00453-w

Bovill, C., \& Bulley, C. J. (2011). A model of active student participation in curriculum design: Exploring desirability and possibility. In C. Rust (Ed.), Improving student learning (ISL) 18: Global theories and local practices: Institutional, disciplinary and cultural variations (No. 18; Issue 18, pp. 176-188). Oxford Brookes University: Oxford Centre for Staff and Learning Development.

http://www.brookes.ac.uk/services/ocsld/books/improving student learning/global theories.html

Bovill, C., Cook-Sather, A., Felten, P., Millard, L., \& Moore-Cherry, N. (2016). Addressing potential challenges in co-creating learning and teaching: Overcoming resistance, navigating institutional norms and ensuring inclusivity in student-staff partnerships. Higher Education, 71(2), 195-208. https://doi.org/10.1007/s10734-015-9896-4 
Braun, V., \& Clarke, V. (2006). Using thematic analysis in psychology. Qualitative Research in Psychology, 3(2), 77-101. https://doi.org/10.1191/1478088706qp063oa

Cates, R. M., Madigan, M. R., \& Reitenauer, V. L. (2018). 'Locations of Possibility': Critical perspectives on partnership. International Journal for Students as Partners, 2(1), 3346. https://doi.org/10.15173/ijsap.v2i1.3341

Cook-Sather, A. (2014). Student-faculty partnership in explorations of pedagogical practice: A threshold concept in academic development. International Journal for Academic Development, 19(3), 186-198. https://doi.org/10.1080/1360144X.2013.805694

Cook-Sather, A., Bahti, M., \& Ntem, A. (2019). Pedagogical partnerships: A how-to guide for faculty, students and academic developers in higher education. Elon University Center for Engaged Learning. https://www.centerforengagedlearning.org/books/pedagogical-partnerships/

Cook-Sather, A., Bovill, C., \& Felten, P. (2014). Engaging students as partners in learning and teaching: A guide for faculty. John Wiley \& Sons.

Cook-Sather, A., Signorini, A., Dorantes, S., Cribb, P., \& Perez, A. (2020). “I never realized...": Shared outcomes of different student-faculty partnership approaches to assessing student learning experiences and evaluating faculty teaching. Journal of Higher Education Theory and Practice, 20(7). https://doi.org/10.33423/ihetp.v20i7.3160

Curtis, N. A., \& Anderson, R. D. (2021). Moving toward student-faculty partnership in systems-level assessment: A qualitative analysis. International Journal for Students as Partners, 5(1), 57-75. https://doi.org/10.15173/ijsap.v5i1.4204

Deeley, S. J., \& Bovill, C. (2017). Staff student partnership in assessment: Enhancing assessment literacy through democratic practices. Assessment \& Evaluation in Higher Education, 42(3), 463-477. https://doi.org/10.1080/02602938.2015.1126551

Deeley, S. J., \& Brown, R. A. (2014). Learning through partnership in assessment. Teaching and Learning Together in Higher Education, 13.

http://repository.brynmawr.edu/tlthe/vol1/iss13/3.

Dianati, S., \& Oberhollenzer, Y. (2020). Reflections of students and staff in a project-led partnership: Contextualised experiences of students-as-partners. International Journal for Students as Partners, 4(1), 1-15. https://doi.org/10.15173/ijsap.v4i1.3974

Dollinger, M., \& Lodge, J. (2020). Student-staff co-creation in higher education: An evidenceinformed model to support future design and implementation. Journal of Higher Education Policy and Management, 42(5), 532-546. https://doi.org/10.1080/1360080X.2019.1663681

Dollinger, M., Lodge, J., \& Coates, H. (2018). Co-creation in higher education: Towards a conceptual model. Journal of Marketing for Higher Education, 28(2), 210-231. https://doi.org/10.1080/08841241.2018.1466756 
Healey, M., Flint, A., \& Harrington, K. (2014). Engagement through partnership: Students as partners in learning and teaching in higher education. Advance HE. https://www.advance-he.ac.uk/knowledge-hub/engagement-through-partnershipstudents-partners-learning-and-teaching-higher

Healey, M., Flint, A., \& Harrington, K. (2016). Students as partners: Reflections on a conceptual model. Teaching \& Learning Inquiry, 4(2), 8-20.

https://doi.org/10.20343/teachlearninqu.4.2.3

Healey, M., \& Healey, R. (2018). 'It depends': Exploring the context-dependent nature of students as partners practices and policies. International Journal for Students as Partners, 2(1), 1-10. https://doi.org/10.15173/ijsap.v2i1.3472

Hunt, L. Y. A., \& Hunt, L. J. (2017). The Importance of a whole-of-department framework in learning partnerships. International Journal for Students as Partners, 1(2). https://doi.org/10.15173/ijsap.v1i2.3091

Luo, B., Matthews, K., \& Chunduri, P. (2019). "Commitment to collaboration": What students have to say about the values underpinning partnership practices. International Journal for Students as Partners, 3(1), 123-139. https://doi.org/10.15173/ijsap.v3i1.3688

Marie, J., \& McGowan, S. (2017). Moving towards sustainable outcomes in student partnerships: Partnership values in the pilot year. International Journal for Students as Partners, 1(2). https://doi.org/10.15173/ijsap.v1i2.3081

Marquis, E., Jayaratnam, A., Mishra, A., \& Rybkina, K. (2018). “I feel like some students are better connected": Students' perspectives on applying for extracurricular partnership opportunities. International Journal for Students as Partners, 2(1), 6481. https://doi.org/10.15173/ijsap.v2i1.3300

Marquis, E., Jayaratnam, A., Lei, T., \& Mishra, A. (2019). Motivators, barriers, and understandings: How students at four universities perceive student-faculty partnership programs. Higher Education Research and Development. https://doi.org/10.1080/07294360.2019.1638349

Marquis, E., Puri, V., Wan, S., Ahmad, A., Goff, L., Knorr, K., Vassileva, I., \& Woo, J. (2016). Navigating the threshold of student-staff partnerships: A case study from an Ontario teaching and learning institute. International Journal for Academic Development, 21(1), 4-15. https://doi.org/10.1080/1360144X.2015.1113538

Matthews, K. E. (2017). Five propositions for genuine students as partners practice. International Journal for Students as Partners, 1(2). https://doi.org/10.15173/ijsap.v1i2.3315 
Matthews, K. E., Cook-Sather, A., Acai, A., Dvorakova, S. L., Felten, P., Marquis, E., \& MercerMapstone, L. (2019). Toward theories of partnership praxis: An analysis of interpretive framing in literature on students as partners in teaching and learning. Higher Education Research \& Development, 38(2), 280-293. https://doi.org/10.1080/07294360.2018.1530199

Matthews, K. E., Dwyer, A., Hine, L., \& Turner, J. (2018). Conceptions of students as partners. Higher Education, 76(6), 957-971. https://doi.org/10.1007/s10734-018$\underline{0257-y}$

Matthews, K. E., Mercer-Mapstone, L., Dvorakova, S. L., Acai, A., Cook-Sather, A., Felten, P., Healey, M., Healey, R. L., \& Marquis, E. (2019). Enhancing outcomes and reducing inhibitors to the engagement of students and staff in learning and teaching partnerships: Implications for academic development. International Journal for Academic Development, 24(3), 246-259. https://doi.org/10.1080/1360144X.2018.1545233

Mercer-Mapstone, L., \& Bovill, C. (2020). Equity and diversity in institutional approaches to student-staff partnership schemes in higher education. Studies in Higher Education, 45(12), 1-17. https://doi.org/10.1080/03075079.2019.1620721

Mercer-Mapstone, L., Dvorakova, S. L., Matthews, K. E., Abbot, S., Cheng, B., Felten, P., Knorr, K., Marquis, E., Shammas, R., \& Swaim, K. (2017). A systematic literature review of students as partners in higher education. International Journal for Students as Partners, 1(1). https://doi.org/10.15173/ijsap.v1i1.3119

Mercer-Mapstone, L., \& Mercer, G. (2018). A dialogue between partnership and feminism: Deconstructing power and exclusion in higher education. Teaching in Higher Education, 23(1), 137-143. https://doi.org/10.1080/13562517.2017.1391198

Naylor, R., Dollinger, M., Mahat, M., \& Khawaja, M. (2021). Students as customers versus as active agents: Conceptualising the student role in governance and quality assurance. Higher Education Research \& Development, 40(5), 1026-1039. https://doi.org/10.1080/07294360.2020.1792850

Office for Students. (2018, March 7). National student survey (worldwide). https://www.officeforstudents.org.uk/advice-and-guidance/student-informationand-data/national-student-survey-nss/

Plattner, H., Meinel, C., \& Leifer, L. (2015). Design thinking research: Making design thinking foundational. Springer.

Ranjan, K. R., \& Read, S. (2016). Value co-creation: Concept and measurement. Journal of the Academy of Marketing Science, 44(3), 290-315. https://doi.org/10.1007/s11747$\underline{014-0397-2}$

Smith, S., Axson, D., Akhyani, K., Arnautu, A., \& Stanimirova, I. (in press). Learning together: A case study of a partnership to co-create assessment criteria. International Journal of Students as Partners. 
Snelling, C. A., Loveys, B. R., Karanicolas, S., Schofield, N. J., Carlson-Jones, W., Weissgerber, J., Edmonds, R., \& Ngu, J. (2019). Partnership through co-creation: Lessons learnt at the University of Adelaide. International Journal for Students as Partners, 3(2), 6277. https://doi.org/10.15173/ijsap.v3i2.3799

University of Sussex. (2020). Access and participation plan (2020-21 to 2024-25). https://www.sussex.ac.uk/study/terms-and-conditions/access-agreements

APPENDIX 1

Table 1. Profile of student participants

\begin{tabular}{|l|l|l|l|}
\hline $\begin{array}{l}\text { PROFILE OF } \\
\text { PARTICIPANTS }\end{array}$ & DEGREE & GENDER & YEAR OF STUDY \\
\hline Student & Anthropology & M & Second \\
\hline Student & $\begin{array}{l}\text { Accounting and } \\
\text { Finance }\end{array}$ & F & Finalist \\
\hline Student & $\begin{array}{l}\text { Business and } \\
\text { Management }\end{array}$ & F & Finalist \\
\hline Student & $\begin{array}{l}\text { Accounting and } \\
\text { Finance }\end{array}$ & F & Second \\
\hline Student & Media Studies & F & Second \\
\hline Student & American Studies & M & Second \\
\hline
\end{tabular}

Table 2. Profile of staff member participants

\begin{tabular}{|l|l|l|}
\hline PROFILE OF PARTICIPANTS & GENDER & ROLE \\
\hline Staff & F & Associate Dean - Project facilitator \\
\hline Staff & M & Academic Developer \\
\hline Staff & F & Learning Technologist \\
\hline Staff & F & Student Academic Success Advisor \\
\hline Staff & F & Director of Teaching and Learning \\
\hline Staff & & \\
\hline Staff & M & Undergraduate Programme Director \\
\hline Staff & F & Undergraduate Programme Director \\
\hline Staff & & Education Lead \\
\hline Staff & F & Education Lead \\
\hline
\end{tabular}


Table 3. Profile of interviewees

\begin{tabular}{|l|l|l|}
\hline INTERVIEWEE & DURATION & DATE \\
\hline Student 1 & 21 minutes and 50 seconds & $02 / 12 / 2020$ \\
\hline Student 2 & 33 minutes 35 seconds & $12 / 12 / 2020$ \\
\hline Student 3 & 27 minutes 53 seconds & $08 / 12 / 2020$ \\
\hline Student 4 & 31 minutes 28 seconds & $10 / 12 / 2020$ \\
\hline Student 5 & 29 minutes 3 seconds & $02 / 12 / 2020$ \\
\hline Staff 1 & 26 minutes 42 seconds & $10 / 12 / 2020$ \\
\hline Staff 2 & 35 minutes 18 seconds & $09 / 12 / 2020$ \\
\hline Staff 3 & 44 minutes 3 seconds & $22 / 01 / 2021$ \\
\hline Staff 4 & 27 minutes 5 seconds & $21 / 01 / 2021$ \\
\hline Staff 5 & 31 minutes & $03 / 02 / 2021$ \\
\hline
\end{tabular}

